\title{
Protecting Soil Health through Organic Recycling by Gujjar and Bakarwal Women in North-West Himalaya, India
}

\author{
Sanjay-Swami* \\ Krishi Vigyan Kendra-Poonch, Sher-e-Kashmir University of Agricultural Sciences and \\ Technology of Jammu, P.O. Poonch-185 101, J\&K, India \\ *Corresponding author
}

\begin{tabular}{|l|}
\hline K e y w o r d s \\
$\begin{array}{l}\text { Soil health, North-West } \\
\text { Himalaya, Gujjar- } \\
\text { Bakarwal women, } \\
\text { Organic recycling, } \\
\text { Traditional knowledge, } \\
\text { Modern techniques }\end{array}$ \\
\hline Article Info \\
\hline $\begin{array}{l}\text { Accepted: } \\
\text { 10 April 2018 } \\
\text { Available Online: } \\
\text { 10 May 2018 }\end{array}$ \\
\hline
\end{tabular}

\section{Introduction}

The nature and extent of women's involvement in agriculture, no doubt, varies greatly from region to region. Even within a region, their involvement varies widely among different ecological sub-zones, farming systems, castes, classes and stages in the family cycle (Sanjay-Swami, 2014). But regardless of these variations, there is hardly any activity in agricultural production, except ploughing in which women are not actively involved. Studies on women in agriculture
Women have played a key role in protecting the soil health through organic recycling from ancient time. Poonch is one of the hilly, tribal, remote, and border districts of Jammu and Kashmir situated in the Pir Panjal range of the North-West Himalaya. The Gujjars and Bakarwals are significant ethnic groups of Poonch district. Gujjar-Bakarwal women are extremely rich in their indigenous knowledge and techniques. They are fully aware that regular recycling of organic wastes in the soil is the most efficient method of maintaining optimum levels of soil organic matter, but the traditional method of preparing and storing FYM followed by the Gujjar-Bakarwal women is faulty. To improve the quality and quantity of composts produced by them, address the issue of acute shortage of chemical ertilizers in the area, and to protect and maintain the soil health, KVK-Poonch initiated


arects of composting techniques. The results are encouraging. Many of the KVK trained girls have set up vermicompost units at their respective villages and earning good income. KVK-Poonch is taking their services as Master Trainer to train more young girls of mujjar-Bakarwal communities in an effect
more effective maintenance of soil health. 
poor and shallow soils (prone to erosion), which is aggravated by heavy migratory grazing which has also led to soil degradation (Fatima and Hussain, 2012). Hilly rural areas in India suffer from very high male temporary and permanent rural-to-urban migration; women farmers have increasingly found themselves becoming major contributors to the agricultural operations. In the Indian Himalayas a pair of bullocks works 1064 hours, a man 1212 hours and a woman 3485 hours in a year on a one hectare farm, a figure that illustrates women's significant contribution to agricultural production (Shiva, 1991).

Poonch is one of the hilly, tribal, remote, and border districts of Jammu and Kashmir situated in the Pir Panjal range of the NorthWest Himalaya. It is bounded by the Indo-Pak Actual Line of Control (ALoC) from three sides. The total geographical area (excluding occupied area) of the district is $1674 \mathrm{sq} \mathrm{km}$. The average size of land holdings is quite low as it is 0.20 ha only. The average annual rainfall in the district is about $1225 \mathrm{~mm}$ with 56 to 73 average rainy days. Higher reaches of Pir Panjal receives snow fall in winter months. Majority of the fields in this district are situated across the hilly slopes. The difficult terrain, scattered land holdings, traditional mode of production, low use of modern inputs, extreme vulnerability to natural events, poor infrastructures and lack of market incentives are the primary constraints affecting the performance of agriculture in this hilly district. These constraints demand a treatment little different from the standard followed in the mainland plain areas. Mostly, farmers of the district are economically backward and uneducated belonging to Gujjar and Bakarwal communities.

The Gujjars (who tend cattle and buffaloes) and Bakarwals (who rear sheep, goats and horses) are significant ethnic groups of
Poonch district. The main occupation of these communities is practicing arable agriculture along with livestock rearing. Livestock is the primary subsistent activity used to meet household food needs as well as supplement farm incomes. The pattern of livestock strength is mainly influenced by various factors such as farm size, cropping pattern, availability of range-lands including fodder and pasture. It is an established fact that the Gujjar-Bakarwal women are much more hardworking as compares to the other tribal women belonging to Bot, Beda, Balti, Mon, Changpa, Garra, Purig, Shin Dard, Brokpa, Gaddi and Sippi tribes of Jammu and Kashmir. They are playing a dominant role in the livestock production and management activities, apart from farm activities. It is common practice in the Gujjar and Bakarwal communities to give animals as part of a women's dowry.

Gujjar-Bakarwal women are extremely rich in their indigenous knowledge and techniques. They are fully aware of that regular recycling of organic wastes in the soil is the most efficient method of maintaining optimum levels of soil organic matter. They have developed and refined this knowledge and techniques over centuries by carrying out farming under diverse, uncertain, risky and fragile ecological conditions. Various examples demonstrate that modern knowledge and advancements either have their origin in the farming communities or have been built upon the knowledge base already existing among these communities.

\section{Traditional way of recycling of organic wastes by Gujjar and Bakarwal women}

Animal wastes are important resources that are used to supplement organic matters and improve soil conditions (Garg et al., 2005). Applying Farm Yard Manure (FYM), locally called as goha or pah, is one of the most 
useful and significant indigenous methods practiced by the Gujjar-Bakarwal women almost in all the villages of the district from ancient time. Application of FYM is a practice which involves using of fully decomposed organic matter of livestock dung, straw, grasses, left over feed etc. An average size cattle produces around 4-6 tonnes of fresh dung per year. The leaves used for animal bedding not only keep the livestock clean and warm but are also used to maintain or enhance the fertility level of the soil as these are used for making organic manure.

For this, the Gujjar-Bakarwal women dump animal dung/wastes regularly in the open at one place in the shape of heap and allow it to degrade naturally without any amendments. After fully decomposition, the FYM is shifted to the fields and mixed thoroughly in the soil. According to scientific studies on organic manures, animal dung used as manure contains on an average of $0.35 \%$ nitrogen, $0.15 \%$ phosphoric acid and $0.20 \%$ potash (ICAR, 1966). More importantly, only about 35,65 and $75 \%$ of the available $\mathrm{N}, \mathrm{P}, \mathrm{K}$, respectively, from the manure are absorbed by the first crop after application (Garg et al., 1973), and the rest are available to subsequent crops as residual effects. The quantity of FYM used for field application depends upon the number of livestock reared, proximity to the forest, extent of land as well as the manpower available. If soil has to be prevented from becoming barren, it is necessary to apply 10 bullock cart loads or 5 tonnes of dung manure for each acre of land. With the application of FYM, earthworms also get introduced in the cropland as large numbers of earthworms are present in the place where organic decomposition of animal dung takes place and increase the fertility of the soils.

Although, it is a time taking process, yet good FYM can be prepared within a period of about 6-8 months of continuous open-air decomposition of animal dung with other leaf litter. Farm women in the higher altitude areas maintain two cattle sheds - one near to their village and another near to their agricultural fields to reduce the labour in carrying the FYM. In this practice, they only shift their livestock from one cattle shed to other according to the growing season of different crops.

\section{Materials and Methods}

It was realized by Krishi Vigyan Kendra, Poonch that the traditional method of preparing and storing FYM followed by the Gujjar-Bakarwal women is faulty. The animal dung together with stable waste and house sweepings is heaped loosely. The loose heap lie exposed to sun and the raw organic matter dry up. In rains, it gets drenched and all the soluble nutrients get leached out from the manure. Also, while the organic matter decomposes, the ammonia etc. escapes in to atmosphere. The wastage of nitrogen rich urine, the loss of nitrogen due to the fermentation of exposed animal dung, washing away of soluble mineral elements by leaching etc. reduce the manurial value of the FYM.

Keeping this in view, KVK-Poonch initiated to impart vocational trainings to young GujjarBakarwal girls on "Scientific Methods of Composting", "Compost Enrichment", and "Vermicompost Production Technology" keeping in mind that their enlightenment to these techniques will improve quality and quantity of composts produced by them, address the issue of acute shortage of chemical fertilizers in the area, and ultimately protect and maintain the soil health of Poonch district (Sanjay-Swami, 2013a). Through these training programmes, it was demonstrated that the loss of nitrogen and mineral elements caused by unscientific handling can be reduced greatly by storing dung in a stone or brick lined pits, mixing large quantities of 
straw and other vegetable matter with animal dung and keeping the heap compact and moist. This encourages bacterial decomposition of raw organic matter, prevents loss of soluble mineral elements through seepage and minimizes nitrogen losses. The quality of manure is also improved by the concentrated feeds given to the cattle. Manure from animal fed on cereal straws, grass hay is much less valuable than that from animals fed on legume hays, grains and concentrates. Use of preservatives also enhances the quality of the manure. Gypsum and super phosphate have proved most promising in preventing escape of ammonia.

Proper compost is an incredibly nutritious soil amendment, buffering the $\mathrm{pH}$ and retaining moisture and oxygen in the soil. It can cool the soil surface and help mitigate erosion by encouraging a vigorous root system boosted by nitrogen, potassium, phosphorus and other nutrients. Composting helps control and suppress plant pathogens, as well as provide food for microorganisms, which keep the soil healthy and balanced. It improves the structure of problematic soils, breaking up heavy clay soils and retaining water better in sandy soils.

There are several improved methods of compost making, which increase the rate of decomposition and minimize the losses of nutrients. Once the major factors behind composting are understood, one can apply them to adjust efforts and turn compost bin, tumbler, or open pile into an efficient composting machine. The real trick is to get the pile to decompose as fast as one can fill it. The rate at which breakdown occurs depends on several factors: oxygenation, temperature, water content, particulate surface area, and the carbon to nitrogen ratio. Moisture is the key factor in composting and one should feel damp, but never wet. When it's over inoculated, it limits the oxygen that bacteria require. Similarly, in too dry compost bacteria cannot survive, thereby slowing down the decomposing process. If compost pile doesn't heat up, it's possible that the compost pile is too wet, too dry, or there is not enough protein (greens). One can measure the temperature with a compost thermometer. Aeration is equally important, as the composting needs oxygen to decompose. A compost tumbler takes out this step by aerating the compost.

Almost all organic material works in a compost pile. A good balance between carbon-rich matter (browns) and nitrogen-rich materials (greens) is prerequisite for fast composting. Brown materials are things like dried leaves and straw, whereas greens constituted grass clippings and kitchen scraps. Active composting requires finding the right mix for compost pile. Ideally, the ratio is 25:1:: C:N (25 parts brown to 1 part green), with small variation as too much carbon will slow the process, while too much nitrogen will cause odor. The right mix of browns and greens, the right amount of moisture, and the ideal aeration and heat from turning are the factors accelerating the process of composting. However, it would be irresponsible to give an exact time frame for when waste will become humus, as several factors will impact how quickly breakdown occurs. Piles created during this time, with shredded materials that are frequently aerated, can be ready in approximately 2-4 months. Properly tended soft waste in warm weather can take as little as 4-6 weeks. Piles prepared in the winter or late fall, created with larger or tougher pieces of waste, or left unattended, will take longer to decay.

When compost is ready, it will be approximately half of its original size. One should not be able to discern individual items placed in the bin. Look for a dark color, crumbly texture, and earthy smell. Slimy compost is a sign that the process was done incorrectly at some point. 


\section{Compost enrichment}

Farm compost is poor in $\mathrm{P}$ content (0.4-0.8 percent). Addition of $\mathrm{P}$ makes the compost more balanced, and supplies nutrient to microorganisms for their multiplication and faster decomposition. The addition of $\mathrm{P}$ also reduces $\mathrm{N}$ losses. Compost can be enriched by: Application of superphosphate, bone meal or phosphate rock (Ramasami, 1975): $1 \mathrm{~kg}$ of superphosphate or bone meal is applied over each layer of animal dung. Low-grade phosphate rock can also be used for this purpose.

Use of animal bones: these can be broken into small pieces, boiled with wood ash leachate or lime water and drained, and the residue applied to the pits. This procedure of boiling bones facilitates their disintegration. Even the addition of raw bones, broken into small pieces and added to the pit, improves the nutrient value of compost significantly.

Wood ash waste can also be added to increase the $\mathrm{K}$ content of compost.

Addition of N-fixing and P-solubilizing cultures (IARI, 1989): The quality of compost can be further improved by the secondary inoculation of Azotobacter, Azospirillum lipoferum, and Azospirillum brasilence (Nfixers); and Bacillus megaterium or Pseudomonas sp. (P solubilizers). These organisms, in the form of culture broth or water suspension of bio-fertilizer products, can be sprinkled when the decomposing material is turned after one month. By this time, the temperature of the compost has also stabilized at about $35^{\circ} \mathrm{C}$. As a result of this inoculation, the $\mathrm{N}$ content of straw compost can be increased by up to 2 percent. In addition to improving $\mathrm{N}$ content and the availability of other plant nutrients, these additions help to reduce the composting time considerably.

\section{Vermicompost}

Vermicompost is organic manure produced as the vermi-cast by earth worm feeding on biological waste material and plant residues. This compost is an odorless, clean, organic material containing adequate quantities of $\mathrm{N}$, $\mathrm{P}, \mathrm{K}$ and several micronutrients essential for plant growth. It has been emerging as an important source in supplementing/ substituting chemical fertilizers in agriculture. Besides higher concentration of available nutrients (macro, secondary and micro) than the ordinary FYM (Jadhav et al., 1997; Sreenivas et al., 2000), it has also been reported to enhance plants ability to fight against insect pests and diseases. It also improves soil structure due to presence of soil binding chemicals and improves physical properties of the soil like soil air, soil temperature, soil water retention and soil mechanical impedance. Due to non-presence of toxic enzymes it is also eco-friendly and it also has beneficial effect on the bio chemical activities of the soil. There is a growing realization that vermicomposting provides the nutrients and growth enhancing hormones necessary for plant growth. The fruits, flowers and vegetables and other plant products grown using vermicompost are reported to have better keeping quality. A growing number of individuals and institutions are taking interest in the production of compost utilizing earthworm activity (Sanjay-Swami, 2013b). Organic manures play an importance role in crop production and sustainable agriculture development. In intensive cropping system, the use of organic manures is very less and resulted to decline in crop yields and increases the soil health problems (Sanjay-Swami, 2017) (Table 1).

\section{Vermicompost production technology}

Diversity of earthworm species varies with different types of soils and hence choosing a 
local or native species of earthworm for the local soil and for vermicomposting is an important step. For Jammu region, the earth worm spp. Eisenia foetida is best suited for vermicompost production due to:

Higher reproductive capacity (40-45 days after their birth)

It can survive easily at $10-35^{\circ} \mathrm{C}$ temperature and $20-60$ percent relative humidity.

Life cycle of this worm is 180 days.

Take $1.5 \mathrm{~g}$ to $7.0 \mathrm{~g}$ food material per day.

The earthworms take 7 weeks to reach adulthood. From the $8^{\text {th }}$ week onwards they deposit cocoons. One mature worm can produce two cocoons per week. Each cocoon produces 3-7 young after an incubation period of 5-10 days depending on the species of worms, quality of feed and general conditions. The resulting increase is about 1200-1500 worms per year. The population doubles in about a month time.

Compost pit of any convenient dimension can be dug in the backyard or in a field. The most convenient pit of easily manageable size is $2 \mathrm{~m}$ $\mathrm{x} 1 \mathrm{~m} \times 0.75 \mathrm{~m}$. A tank may be constructed with brick and mortar with proper water outlets, or a plastic crate $(600 \mathrm{~mm} \times 300 \mathrm{~mm}$ x $300 \mathrm{~mm}$ ) with holes drilled at the bottom or empty wooden crates or well rings made of cement or clay of $750 \mathrm{~mm}$ diameter and 300 to $450 \mathrm{~mm}$ height can also be used with slight modifications in the thickness of layers used. Vermi-bed (vermes= earthworms; bed= bedding) is the actual layer of good moist loamy soil placed at the bottom, about 150 to $200 \mathrm{~mm}$ thick above a thin layer $(50 \mathrm{~mm})$ of broken bricks and coarse sand. Earthworms are introduced into the loamy soil, which the worms will inhabit as their home. About 100 earthworms (a combination of epigeics and anecics) may be introduced into a compost pit of about $2 \mathrm{~m} \times 1 \mathrm{~m} \times 0.75 \mathrm{~m}$, with a vermin-bed of about 15 to $20 \mathrm{~cm}$ thick. The vermi-bed should always be kept moist, but should never be flooded.

Handful lumps of fresh cattle dung are then placed at random over the vermi-bed. The compost pit is then layered to about $50 \mathrm{~mm}$ with dry leaves or preferably chopped hay/straw. For the next 30 days the pit is kept moist by watering it whenever necessary. The bed should neither be dry nor soggy. The pit may then be covered with coconut or Palmyra leaves or an old jute (gunny) bag to discourage birds. Plastic sheets on the bed are to be avoided as they trap heat. After the first 30 days, as above, wet organic waste of animal and/or plant origin from the kitchen or hotel or hostel or farm that has been pre-digested is spread over it to a thickness of about $50 \mathrm{~mm}$. This can be repeated twice a week. All these organic wastes can be turned over or mixed periodically with a pickaxe or a spade. Care should be taken not to disturb the vermi-bed in which the worms live. Keep adding garbage till the compost pit is nearly full. Continue to keep the pit moist for another 30 to 45 days, turning over the material in the pit with care avoiding injury to the worms. Turning over can be done on every fifth or seventh day with the help of a forked spade. Regular watering should be done to keep the right amount of moisture in the pits. In 60 to 90 days, the compost should be ready as indicated by the presence of earthworm castings (vermicompost) on the top of the bed. The compost should be turned occasionally since this allows for aeration. If the weather is very dry it should be dampened periodically. The pile should be moist not wet and soggy. Vermicompost can now be harvested from the bin/pit. The material should be placed in a heap in the sun so that most of the worms move down to the cool base of the heap. The compost is then sieved before being packed. 


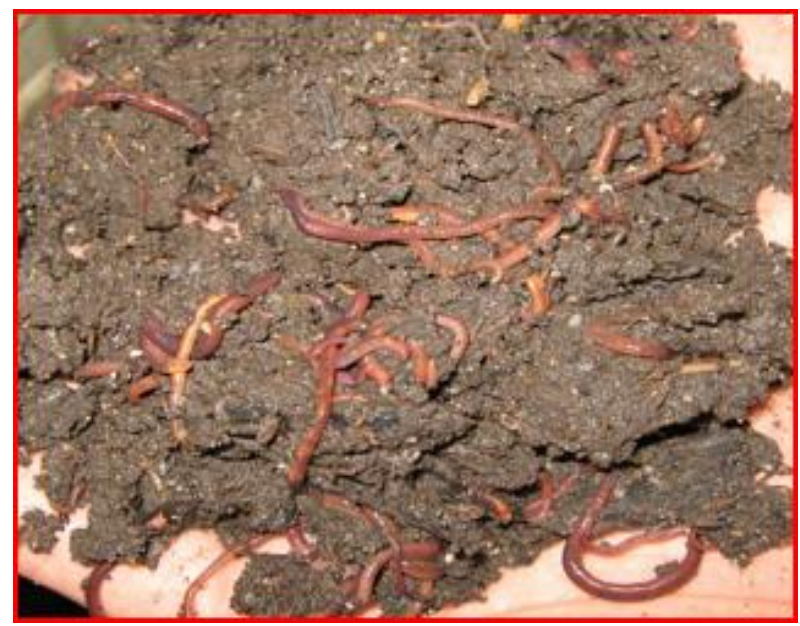

Plate.1 Versatile waste eater and decomposer Eisenia foetida

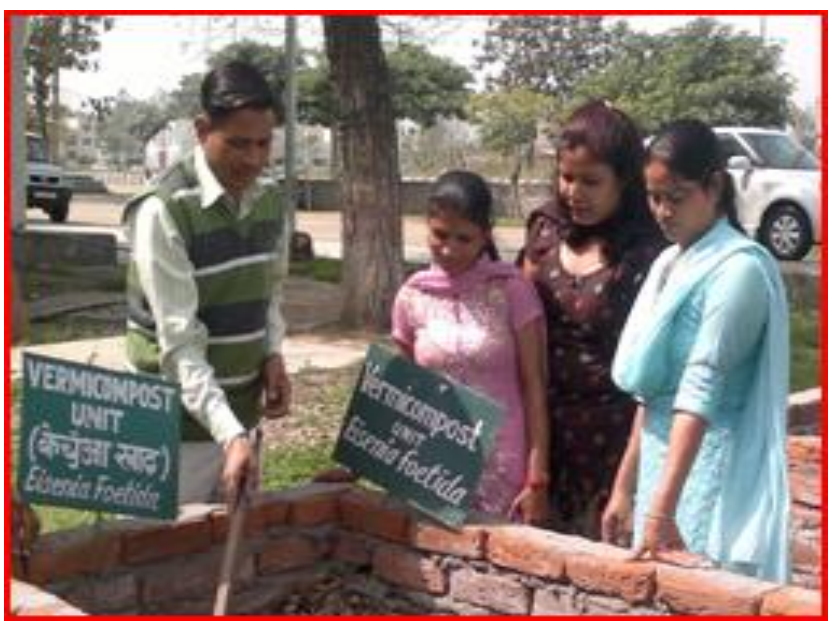

Plate.2 Vocational training on vermicompost production technology at KVK

Table.1 Nutrient profile of vermicompost and farm yard manure*

\begin{tabular}{|l|c|c|}
\hline Nutrient & Vermicompost & Farm Yard Manure \\
\hline $\mathrm{N}(\%)$ & 1.6 & 0.5 \\
\hline $\mathrm{P}_{2} \mathrm{O}_{5}(\%)$ & 0.7 & 0.2 \\
\hline $\mathrm{K}_{2} \mathrm{O}(\%)$ & 0.8 & 0.5 \\
\hline $\mathrm{Ca}(\%)$ & 0.5 & 0.9 \\
\hline $\mathrm{Mg}(\%)$ & 0.2 & 0.2 \\
\hline $\mathrm{Fe}(\mathrm{ppm})$ & 175.0 & 146.5 \\
\hline $\mathrm{Mn}(\mathrm{ppm})$ & 96.5 & 69.0 \\
\hline $\mathrm{Zn}(\mathrm{ppm})$ & 24.5 & 14.5 \\
\hline $\mathrm{Cu}(\mathrm{ppm})$ & 5.0 & 2.8 \\
\hline $\mathrm{C}: \mathrm{N}$ Ratio & 15.5 & 31.3 \\
\hline
\end{tabular}

* These values are subject to variation depending upon the type of organic waste.

The earthworms and the thicker material, which remains on top of the sieve, go back in the bin and the process starts again.

\section{Vermicomposting vs. traditional composting}

Less labor intensive: When we say "organic materials," we mean the following waste can be added: food, leaves, grains, and natural cloths (such as cotton). In traditional composting, you need to stock pile in preparation for the next "batch." Vermicomposting, however, is less labor intensive, as it requires little turning/aerating necessary because the worm activity helps to mix, fragment, and aerate waste.

Great for both small and large spaces: In addition, vermicomposting does not require as much space as traditional compost piles. It only requires a bin approximately 8 to 16 inches deep with 1 to 2 square feet of surface area, and thus creates the ability to have indoor systems and when vermicomposting outdoors, the space used can grow as large as the Herdsman can feed the worms.

Can be done round the year: Weather is a key factor in composting. Traditional composting 
methods slowdown in very cold weather, but vermicomposting allows for true year round composting. Since vermicomposting can be done in indoor spaces, it is spared any inclement weather and can be done yearround. With the ability to continuously feed, Nature's Little Recyclers can feed their outside vermicomposting systems year round through innovative practice (Hubbard, 2018).

\section{Results and Discussion}

The young Gujjar-Bakarwal girls, who were trained by KVK-Poonch, are now convinced about the importance of organic manures/composts. They feel that as the availability of the good quality organic manure is the problem, the vermicompost production is a viable option to produce the good quality compost in a short time. Many of the KVK trained girls have set up vermicompost units at their respective villages and earning good income. KVKPoonch is taking their services as Master Trainer to train more young girls of GujjarBakarwal communities in an effective manner.

According to Narayana Reddy (2006), maintaining a soil carbon content of at least 2.0 per cent is a must for sustainable agriculture. However, due to use of indiscriminate nitrogenous chemicals and discontinued use of organic manures, this has come down from three percent to less than 0.5 percent, in the past 50 years. Tracing out the history, we find that one Sir Albert Howard, who was in India in 1905, as Imperial Economic Botanist working in the Indian Agriculture Research Institute, studied the Indian system of Agriculture in order to consider ways and means of improving it. He observed in 1926, as President of the Indian Science Congress, that soil reserves should not be exploited and Indian Agriculture must be brought the know-how to transfer capital in the shape of soil fertility. According to him, the Indian Agriculture has been traditional by faithfully copying nature and use of urine and dung of the livestock was a crucial factor in organic farming in India.

The Gujjar-Bakarwal women of Poonch district are playing a significant role in protecting soil health through organic recycling from ancient time, but the traditional method of preparing and storing FYM followed by the Gujjar-Bakarwal women is faulty. Realizing the need of hour, KVK-Poonch initiated to impart vocational trainings to young girls of Gujjar-Bakarwal communities on "Scientific Methods of Composting", "Compost Enrichment", and "Vermicompost Production Technology" keeping in mind that their enlightenment to these techniques will improve quality and quantity of composts produced by them, address the issue of acute shortage of chemical fertilizers in the area, and ultimately protect and maintain the soil health of Poonch district.

In this way, KVK-Poonch has moved towards more effective maintenance of soil health by enlightening the young tribal girls of Gujjars and Bakarwals about these practices. The uniqueness of these practices is their suitability to the local conditions, their economic feasibility and easy implementation. As one practice compliments the other one, if they are applied in combination, they tend to be even more effective in protecting and maintaining soil health.

\section{Acknowledgement}

The author would like to acknowledge the ICAR-Agricultural Technology Application Research Institute, Zone-1, Ludhiana, Punjab for releasing funds to carry out the interventions. 


\section{References}

Fatima, K. and Hussain, A. (2012). Problems and Prospects of Hill Farming. Research Journal of Agricultural Sciences, 3 (2): 578-580.

Garg, A. C., Idnani, M. A. and Abraham, T. P. (1973). Organic Manure. Tech Bulletin (Agril) 32, Indian Council of Agricultural Research, New Delhi.

Garg, V.K., Chand, S., Chhillar, A. and Yadav, A. (2005). Growth and reproduction of Eisenia foetida in various animal wastes during vermicomposting. Appl. Ecol. Environ. Res. 3(2): 51-59.

Hubbard, Ed. (2018). Ways Vermicomposting is Better than Traditional Composting. Nature's Little Recyclers, online at https://nlrworms.com/blogs/education/w ays-vermicomposting-is-better-thantraditional-composting.

IARI (1989). Bio-fertilizers. Division of Microbiology, Indian Agricultural Research Institute, New Delhi.

ICAR (1966). Handbook of Agriculture. Indian Council of Agricultural Research, New Delhi. p. 105.

IUCN (2003). Maximizing Conservation in Protected Areas: Guidelines for Gender Consideration. Policy Brief, International Union for Conservation of Nature (IUCN)-ORMA, San José, Costa Rica.

Jadhav, A. D., Talashilkar, S.C. and Pawar, A.G. (1997). Influence of conjunctive use of FYM, vermicompost and urea on growth and nutrient uptake in rice.
Journal of Maharashtra Agricultural Universities, 22 (2): 249-250.

Narayana, R. L. (2006). Natural Regeneration Processes at Work. LEISA India. 8(4): 27.

Ramasami, S. (1975). Processing of Bones into Bonemeal and Its Effect on Plant Growth. Indian Agricultural Research Institute, New Delhi (PhD Thesis).

Sanjay-Swami (2013a). "Role of KVKPoonch in Technology Transfer", Regional Voice, 29 October, 2013, p. 04.

Sanjay-Swami (2013b). "Vermicomposting: Transforming Garbage into Gold", Online at www.krishisewa.com

Sanjay-Swami (2014). "Bridging the Gap: KVK-Poonch: Empowering Women in Agriculture", Regional Voice, 15 January, 2014, p. 04.

Sanjay-Swami (2017). Organic farming: A way towards maintaining soil health, improving crop productivity and livelihood security of tribals in NE India. In: Enhancing Socio-economic Status and Livelihood Security of Tribal Farmers of Meghalaya, (Eds.) Ram Singh, N.S. Azad Thakur, K. Noren Singh, Rajkumar Josmee Singh, L. Devarani and Kennedy N., CPGS, CAU, Barapani, pp. 33-40.

Shiva, V. (1991). "Most Farmers in India are Women" FAO, New Delhi.

Sreenivas, C., Muralidhar, S. and Rao, M. S. (2000). Vermicompost: A viable of IPNSS in nitrogen nutrition of ridge gourd. Annals of Agricultural Research, 21 (1): 108-113.

\section{How to cite this article:}

Sanjay-Swami. 2018. Protecting Soil Health through Organic Recycling by Gujjar and Bakarwal Women in North-West Himalaya, India. Int.J.Curr.Microbiol.App.Sci. 7(05): 10751083. doi: https://doi.org/10.20546/ijcmas.2018.705.131 